\section{An Overview of the Kauffman Firm Survey}

Results from 2010 Business Activities

May 2012

Prepared By:

Alicia Robb

E.J. Reedy

Kauffman

Firm Survey

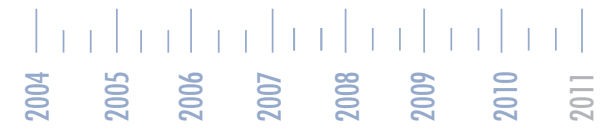
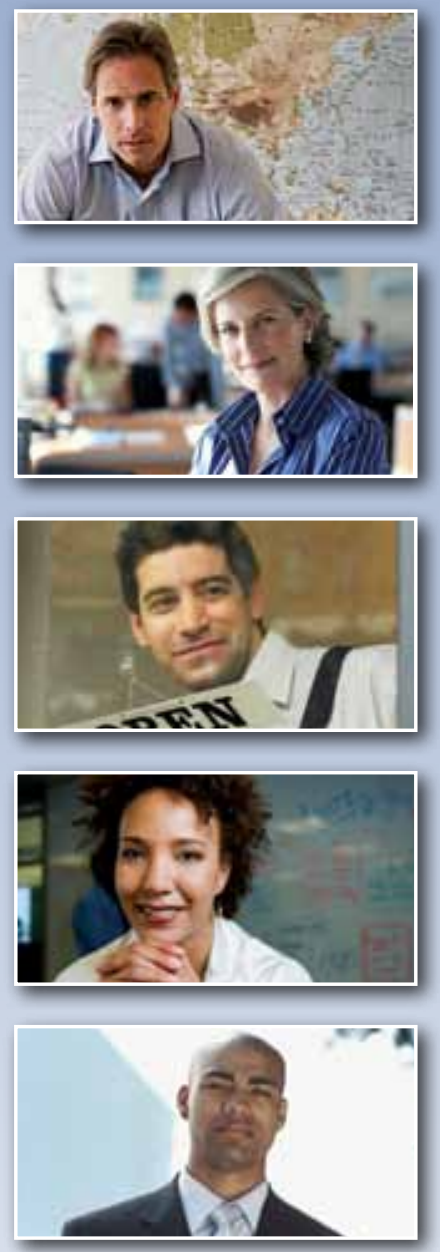


\section{Kauffman Firm Survey

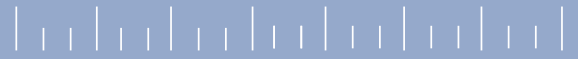

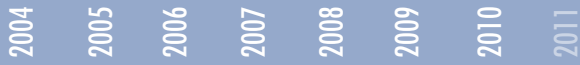




\section{An Overview of the Kauffman Firm Survey \\ Results from 2010 Business Activities}

Prepared By:

Alicia Robb

E.J. Reedy

May 2012

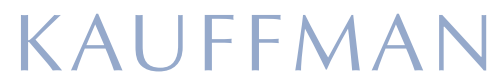

The Foundation of Entrepreneurship 


\section{An Overview of the Kauffman Firm Survey \\ Results from 2010 Business Activities}

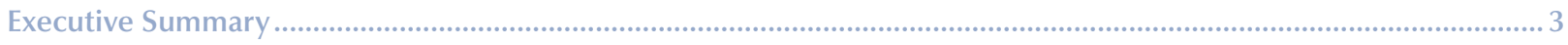

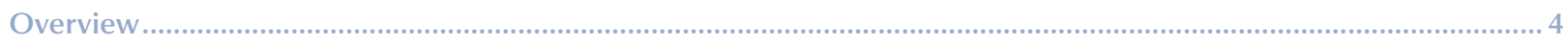

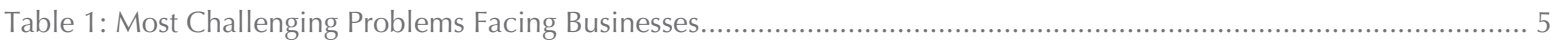

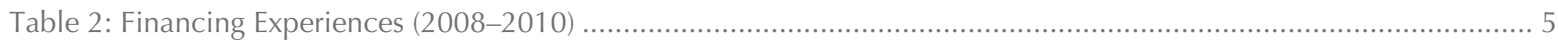

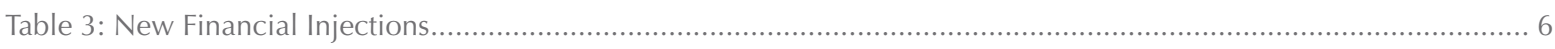

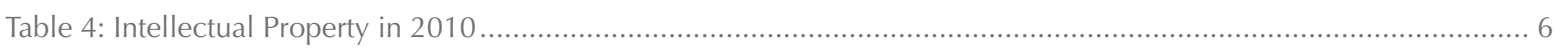

Table 5: Spending on Research \& Development and Intangible Assets .................................................................. 7

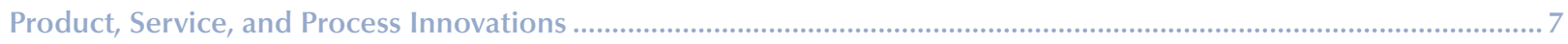

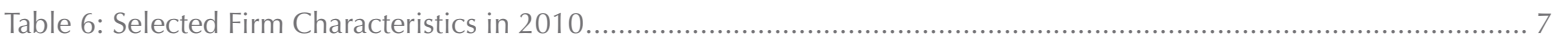

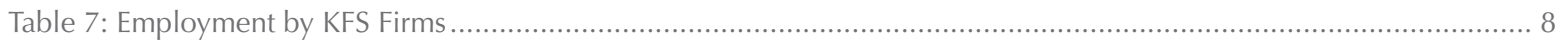

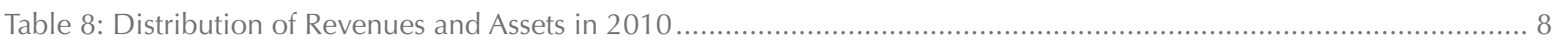

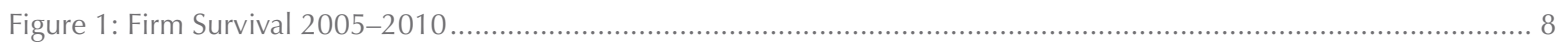




\section{Executive Summary}

Although entrepreneurial activity is an important part of a capitalist economy, data about U.S. businesses in their early years of operation have been extremely limited. ${ }^{1}$ Only recently has it become apparent what important contributions new and young businesses make to job creation and innovation activities. ${ }^{2}$ As part of an effort to understand the dynamics of new businesses in the United States, the Ewing Marion Kauffman Foundation (the Foundation) sponsored the Kauffman Firm Survey (KFS), a panel study of new businesses founded in 2004 that are being tracked annually over their first eight years of operation. Tracking businesses over time allows us to follow business evolutions that would not be apparent in cross-sectional snapshots, the more typical collection method. The KFS dataset provides researchers with a unique opportunity to study a panel of new businesses from startup to sustainability (or exit), with longitudinal data centering on topics such as how businesses are financed; the products, services, and innovations these businesses possess and develop in their early years of existence; and the characteristics of those who own and operate them.

Data currently are available through calendar year 2010, the seventh year of operations for continuing businesses. Additionally, since our panel came into existence before the most recent recession, following these businesses allows us to get a picture of how young businesses in the United States have recovered or been affected. A series of tables give a broad overview of the 4,928 businesses included in the Kauffman Firm Survey that are nationally representative of startups from 2004. Highlights include:

- Problems. More than credit or falling real estate values, the most challenging problems reported by young businesses continue to be slow or lost sales and unpredictable business conditions. Slow or lost sale problems have fallen from
2008 (down by 9 percentage points), while problems with payments from clients has increased from only 2 percent in 2008 to 12.8 percent in 2009 and 14.1 percent in 2010.

- For firms seeking new credit or renewal of existing credit in 2010, about 40 percent had their applications sometimes or always denied, similar to 2009 levels, and up from about 33 percent in 2008. The most common reasons reported by the firms for denial were banks putting additional restrictions on lending and insufficient collateral. About 20 percent of business owners indicated that they didn't apply for funding at some point when they needed credit in 2010 because they feared their application would be denied.

- By 2010, about half of all firms in the sample that started in 2004 had permanently closed. The overall survival rate for the 2004 startups was 49 percent by the end of 2010, compared with 56 percent for yearend 2009.

- A small but significant set of firms reported making investments in research, intellectual property, or future-year operations. More than 45 percent of firms made investments in intangible assets meant to show future-year gain in 2010, compared with just 12 percent of firms investing in research and development (R\&D). Intangible asset spending averaged $\$ 17,000$ in 2010, while average R\&D spending was more than $\$ 63,000$. High-tech firms are much more likely to have patents, copyrights, or trademarks.

- Nearly 20 percent of KFS firms indicated that they introduced some product or service innovation in 2010. Additionally, about 14 percent of firms stated that they introduced a new or significantly improved process in the production of goods or provision of services by their firms in 2010. Finally, nearly two-thirds of firms indicated that they introduced a product or service that was new to one of their markets.

1. http://www.nap.edu/catalog/11844.html.

2. A separate series of articles from the Kauffman Foundation explores some of these concepts in more depth. http://www.kauffman.org/researchand-policy/firm-formation-and-economic-growth-research-series.aspx. 
- While about 40 percent of firms had employees in 2004, by 2010 about 52 percent of surviving firms had employees. Surviving firms with employees, which are now in their seventh year of operations, increased average employment to 7.5 employees in 2010.

- In 2010, about one-third of firms had revenues greater than $\$ 100,000$, and 11 percent had revenues of more than a million dollars.

Further analysis is available in papers that are posted to the KFS section of the Ewing Marion Kauffman Foundation website as they are completed (http:// www.kauffman.org/kfs/).

\section{Overview}

The Kauffman Firm Survey (KFS) is the largest, longest longitudinal survey of new businesses in the world. At the end of the project, the KFS will contain data over the 2004-2011 period on 4,928 firms that began operations in 2004 . This latest report focuses on data collected in the firms' seventh year of existence (calendar year 2010). ${ }^{3}$ The study created the panel by using a random sample from the Dun \& Bradstreet (D\&B) database list of new businesses started in 2004.

The KFS sought to create a panel that included new businesses created by a person or team of people, purchases of existing businesses by a new ownership team, and purchases of franchises. A series of questions was asked about indicators of business activity and whether these were conducted for the first time in the reference year (2004). These indicators included: 1) payment of state unemployment (UI) taxes; 2) payment of Federal Insurance Contributions Act (FICA) taxes; 3) presence of a legal status for the business; 4) use of an Employer Identification Number (EIN); and 5) use of Schedule $C$ to report business income on a personal tax return. To be "eligible" for the KFS, at least one of these activities had to have been performed in 2004 and none performed in a prior year. The questionnaire covered a variety of topics, including business characteristics, strategy and innovation, business structure and benefits, financing, and demographics of the principals. The
KFS currently contains data on the baseline (calendar year 2004) and six follow-up years (2005-2010).

The Kauffman Firm Survey is a research dataset accessible to scholars around the globe. The publicuse microdata file for the Kauffman Firm Survey is available at http://www.kauffman.org/kfs/. The University of Chicago NORC Data Enclave provides secure remote access to a confidential version of the KFS microdata file, which contains more detail regarding industry codes, geographical codes (zip code, metropolitan statistical area, and state), and many additional continuous variables (in addition to categorical variables). Details on applying to the NORC enclave can be found on the KFS website: http://www.kauffman.org/kfs/.

While 2004 was an average year in many respects, these new firms faced an economic crisis in their early years of operation that was anything but average. This crisis began in 2008 and continued to affect the firms in the KFS survey. When asked about the most challenging problem they faced, the most-cited problem was slow and/or lost sales, followed by the unpredictability of business conditions (Table 1). The percentage of firms citing customers or clients not making payments or paying late continued to rise, up to 14.1 percent in 2010, compared with just 2 percent in 2008. Credit access and the terms or cost of credit continued to be cited as the most challenging problem by only a small percentage of firms.

Yet, when asked to report if they applied for and obtained loans or lines of credit and the reasons why these applications were not filed or were denied, access to credit still seems to be an issue for many firms (Table 2). In 2010, most firms (89 percent) did not apply for new loans or for the renewal of existing lines of credit, an increase from about 87 percent in 2008. For the 11 percent of firms that applied for borrowing, 60 percent report always being approved for new financing, while 16 percent were sometimes approved and 23 percent were denied. Of the firms that faced denied applications, 91 percent report being denied because of banks putting tighter restrictions on their lending, and nearly 40 percent report being denied

3. Previous reports can be found at http://www.kauffman.org/research-and-policy/kauffman-firm-survey.aspx. 
Table 1: Most Challenging Problems Facing Businesses

\begin{tabular}{|c|c|c|c|}
\hline Slow or lost sales & $53.0 \%$ & $44.1 \%$ & $43.8 \%$ \\
\hline The unpredictability of business conditions & $24.0 \%$ & $21.6 \%$ & $23.7 \%$ \\
\hline Customers or clients not making payments or paying late & $2.0 \%$ & $12.8 \%$ & $14.1 \%$ \\
\hline Other & $10.0 \%$ & $7.8 \%$ & $7.6 \%$ \\
\hline Falling real estate values & $5.0 \%$ & $6.9 \%$ & $5.7 \%$ \\
\hline An inability to obtain credit & $4.0 \%$ & $4.8 \%$ & $4.4 \%$ \\
\hline The cost and/or terms of credit & $2.0 \%$ & $2.1 \%$ & $0.8 \%$ \\
\hline
\end{tabular}

Source: KFS Microdata Most Challenging

Table 2: Financing Experiences (2008-2010)

\begin{tabular}{|c|c|c|c|}
\hline Applied for new bank credit or renewed lines of credit & $12.6 \%$ & $12.3 \%$ & $11.1 \%$ \\
\hline $\begin{array}{l}\text { Loan application(s) outcome(s) } \\
\text { Always approved } \\
\text { Sometimes approved } \\
\text { Sometimes denied } \\
\text { Always denied }\end{array}$ & $\begin{array}{l}67.6 \% \\
17.5 \% \\
14.9 \%\end{array}$ & $\begin{array}{l}60.3 \% \\
16.7 \% \\
22.9 \%\end{array}$ & $\begin{array}{l}60.7 \% \\
16.0 \% \\
23.3 \%\end{array}$ \\
\hline $\begin{array}{l}\text { Reason(s) for denial } \\
\text { Banks putting tighter restrictions on lending } \\
\text { Insufficient collateral } \\
\text { Business credit history } \\
\text { Personal credit history } \\
\text { Loan too large } \\
\text { Inadequate documentation } \\
\text { Business too new } \\
\text { Other }\end{array}$ & $\begin{array}{r}\mathrm{n} / \mathrm{a} \\
42.2 \% \\
33.3 \% \\
45.0 \% \\
28.0 \% \\
15.6 \% \\
15.7 \% \\
14.7 \%\end{array}$ & $\begin{array}{r}89.5 \% \\
42.1 \% \\
35.0 \% \\
44.3 \% \\
16.6 \% \\
5.3 \% \\
14.2 \% \\
3.4 \%\end{array}$ & $\begin{array}{c}91.0 \% \\
39.3 \% \\
28.5 \% \\
37.4 \% \\
16.7 \% \\
3.8 \% \\
7.4 \% \\
4.2 \%\end{array}$ \\
\hline $\begin{array}{l}\text { Loan requiring collateral } \\
\text { Accounts receivable } \\
\text { Vehicle/equipment } \\
\text { Security deposit } \\
\text { Intellectual property } \\
\text { Business real estate } \\
\text { Personal real estate } \\
\text { Other personal assets } \\
\text { Other }\end{array}$ & $\begin{array}{l}\mathrm{n} / \mathrm{a} \\
\mathrm{n} / \mathrm{a} \\
\mathrm{n} / \mathrm{a} \\
\mathrm{n} / \mathrm{a} \\
\mathrm{n} / \mathrm{a} \\
\mathrm{n} / \mathrm{a} \\
\mathrm{n} / \mathrm{a} \\
\mathrm{n} / \mathrm{a} \\
\mathrm{n} / \mathrm{a}\end{array}$ & $\begin{array}{r}\mathbf{1 5 . 6 \%} \\
39.7 \% \\
35.6 \% \\
19.0 \% \\
3.0 \% \\
20.0 \% \\
42.7 \% \\
17.4 \% \\
5.4 \%\end{array}$ & $\begin{array}{r}14.9 \% \\
47.5 \% \\
49.9 \% \\
17.2 \% \\
3.0 \% \\
23.0 \% \\
31.6 \% \\
21.9 \% \\
1.6 \%\end{array}$ \\
\hline Did not apply for debt financing when needed for fear of denial & $17.6 \%$ & $21.3 \%$ & $19.2 \%$ \\
\hline Applied for external equity financing but did not receive & $\mathrm{n} / \mathrm{a}$ & $4.7 \%$ & $4.6 \%$ \\
\hline
\end{tabular}

Source: KFS Microdata

for not having sufficient collateral. Credit history was cited often as a reason to deny credit, with business credit history being an issue in 29 percent of the cases and personal credit history cited in 37 percent of the cases. About 19 percent of the firms did not apply for credit at some point when they needed it in 2010 because they thought their applications would be denied. Finally, about 5 percent of firms applied for, but did not receive, external equity financing (from sources such as venture capitalists, angel investors, and other businesses). 
Only 46 percent of firms made new investments in their businesses from debt financing in 2010, down from half in 2009 and 53 percent in 2008. Less than one-quarter of firms made new equity investments in 2010, which was similar to 2009 and down from 2008. Investment levels also continued to drop over the period, with just 18 percent of firms investing more than $\$ 25,000$ in debt capital, compared with 21 percent in 2009 and 24 percent in 2008. Similarly, just 7 percent of firms invested more than $\$ 25,000$ in equity capital in 2010 , which was the same as 2009 and down from 9 percent in 2008.

Table 3: Financial Injections

\begin{tabular}{|c|c|c|c|c|c|c|}
\hline rinancrai injections & Debt & Equity & Debt & Equity & Debt & Equity \\
\hline None & $47 \%$ & $66 \%$ & $50 \%$ & $74 \%$ & $54 \%$ & $74 \%$ \\
\hline$\$ 5,000$ or less & $14 \%$ & $13 \%$ & $14 \%$ & $8 \%$ & $13 \%$ & $10 \%$ \\
\hline$\$ 5,001$ to $\$ 25,000$ & $16 \%$ & $12 \%$ & $16 \%$ & $11 \%$ & $14 \%$ & $10 \%$ \\
\hline$\$ 25,001$ to $\$ 100,000$ & $14 \%$ & $7 \%$ & $13 \%$ & $5 \%$ & $11 \%$ & $5 \%$ \\
\hline$\$ 100,001$ or more & $10 \%$ & $2 \%$ & $8 \%$ & $2 \%$ & $7 \%$ & $2 \%$ \\
\hline
\end{tabular}

Source: KFS Microdata

High-tech firms are identified using six-digit 2010 NAICS industry codes that have science- and engineering-intensive occupations, whose shares of employment in those occupations were three times the national average, or industries that exceeded the U.S. average for both research and development expenditures per employee and for the proportion of full-time-equivalent R\&D scientists and engineers in the industry workforce. High-tech firms were more likely than non-high-tech firms to state that they had a comparative advantage in the products and/or services they offered. They also were much more likely to state that their comparative advantage came from partnering with another company, university, or government lab. They were four times as likely to state that having patents was a source of comparative advantage. The holding of patents, copyrights, and trademarks is highly concentrated among high-tech sector firms. These firms are much more likely to have patents, copyrights, or trademarks.

Table 4: Intellectual Property in 2010

\begin{tabular}{|c|c|c|c|}
\hline & All & High-Tech & Not High-Tech \\
\hline Comparative Advantage & $44.9 \%$ & $55.4 \%$ & $44.1 \%$ \\
\hline $\begin{array}{l}\text { Sources of Comparative Advantage } \\
\text { University Partnership } \\
\text { Company Partnership } \\
\text { Gov't Lab Partnership } \\
\text { Patents }\end{array}$ & $\begin{array}{r}6.8 \% \\
26.5 \% \\
2.7 \% \\
5.8 \%\end{array}$ & $\begin{array}{r}9.8 \% \\
41.6 \% \\
5.2 \% \\
20.3 \%\end{array}$ & $\begin{array}{r}6.5 \% \\
25.1 \% \\
2.5 \% \\
4.5 \%\end{array}$ \\
\hline Have Patents & $2.9 \%$ & $9.3 \%$ & $2.4 \%$ \\
\hline Have Copyrights & $9.1 \%$ & $21.5 \%$ & $8.2 \%$ \\
\hline Have Trademarks & $12.9 \%$ & $20.6 \%$ & $12.4 \%$ \\
\hline
\end{tabular}

Source: KFS Microdata 
Nearly half of firms (45.1 percent) had new spending on intangible assets in 2010. These are expenditures expected to produce long-term benefits for businesses, such as brand development and worker training. Only about 12 percent of firms invested in research and development (R\&D) in 2010. However, R\&D investments were higher, averaging about $\$ 62,000$, compared with just $\$ 17,000$ on tangible assets.

Table 5: Spending on Research \& Development and Intangible Assets

\begin{tabular}{|l|r|}
\hline Firms with R\&D Spending & $11.6 \%$ \\
Amount of R\&D Spending & $\$ 62,621$ \\
\hline Firms with Intangible Asset Spending & $45.1 \%$ \\
Amount of Intangible Asset Spending & $\$ 17,017$ \\
\hline Intangible Asset Spending in 2010 & \\
\hline$\$ 500$ or less & $12.6 \%$ \\
$\$ 501-\$ 5,000$ & $41.7 \%$ \\
$\$ 5,001-\$ 25,000$ & $26.1 \%$ \\
$\$ 25,001-\$ 100,000$ & $13.9 \%$ \\
$\$ 100,001$ or more & $5.7 \%$ \\
\hline Total & $100.0 \%$ \\
\hline
\end{tabular}

Source: KFS Microdata

\section{Product, Service, and Process Innovations}

Product or service innovations are new products or services or a significantly improved product or service introduced by a business. Nearly 20 percent of KFS firms indicated that they introduced some product or service innovation in 2010. Additionally, about 14 percent of firms stated that they introduced a new or significantly improved process in the production of goods or provision of services by their firms in 2010 . Finally, nearly two-thirds of firms indicated that they introduced a product or service that was new to one of their markets. Interestingly, while most of the markets were regional or national, about one-third of those firms indicated that they introduced a product or service to the international market.

In terms of the customer base, most KFS firms sold to individuals (53 percent of sales) and other businesses (41 percent of sales), while only about
6.5 percent of sales went to government customers. Less than 20 percent of firms had a predominantly national customer base, while about two-thirds of firms sold to customers in the same city, county, or state. Only about 11 percent had a neighborhood base as their primary customer location, and just 3.1 percent were predominantly international.

Table 6: Selected Firm Characteristics in 2010

\begin{tabular}{|c|}
\hline $\begin{array}{l}\text { Introduction of products or services } \\
\text { that were new or significantly improved ....... 19.5\% }\end{array}$ \\
\hline $\begin{array}{l}\text { Introduction of processes that were new } \\
\text { or significantly improved .................................13.8\% }\end{array}$ \\
\hline 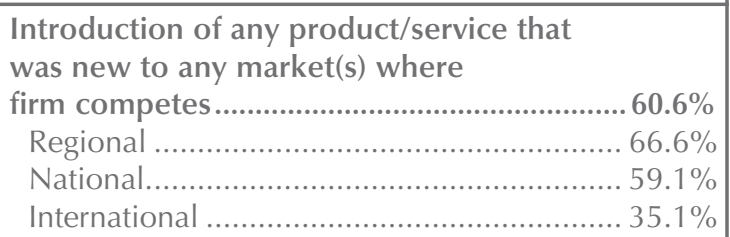 \\
\hline 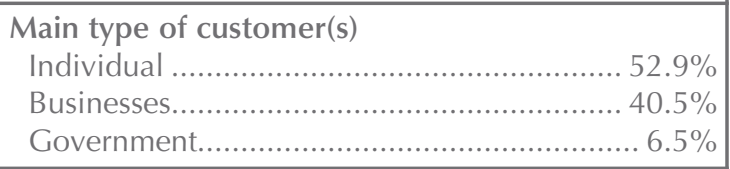 \\
\hline $\begin{array}{l}\text { Where most of the firms' customers } \\
\text { are located } \\
\text { In neighborhoods local to the business ....... } 11.0 \% \\
\text { In the same city or county ...................... } 30.6 \% \\
\text { In the same region, such as in } \\
\text { nearby counties or states } \\
\text { Nationwide }\end{array}$ \\
\hline 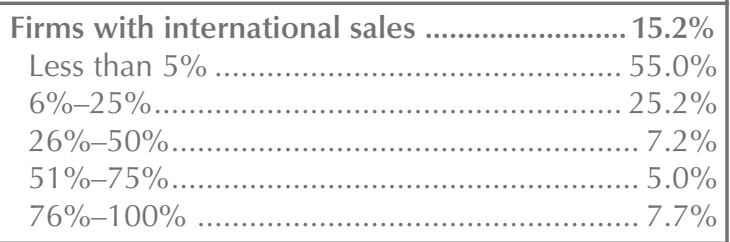 \\
\hline 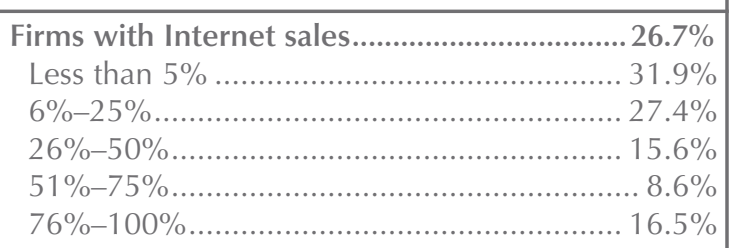 \\
\hline Firm website......................................................... 47.4\% \\
\hline Firm email.....................................................97.5\% \\
\hline
\end{tabular}


About 15 percent of firms indicated that they had international sales. However, more than half stated that those sales made up less than 5 percent of their total revenues. About 13 percent of firms indicated that international sales made up half or more of their annual revenues.

More than a quarter of firms sold their goods or services over the Internet. However, nearly one-third of those indicated that Internet sales made up less than 5 percent of their total sales. Yet, about onequarter of the firms indicated that Internet sales made up at least half of their annual revenues. By 2010 nearly all (97.5 percent) firms had an email account, while nearly half (47.4 percent) had a website. The Internet has clearly touched the vast majority of firms.

While only about 40 percent of firms had employees other than the firm owner(s) in 2004, by 2010, 52.2 percent of firms had employees. Overall, firms averaged less than four employees, but for firms with employees, the number averaged 7.5, compared with just 4.6 employees in 2004 . Thus, surviving firms grew substantially over the period 2004-2010.

\begin{tabular}{|c|c|c|}
\hline $\begin{array}{c}\text { Table } 7 \\
\text { Employment by KFS Firms }\end{array}$ & All Firms & $\begin{array}{c}\text { Surviving } \\
\text { Firms }\end{array}$ \\
\hline & 2004 & 2010 \\
\hline Firms with employees & $40.9 \%$ & $52.2 \%$ \\
\hline Average employment & 1.9 & 3.9 \\
\hline $\begin{array}{l}\text { Average employment } \\
\text { (employers only) }\end{array}$ & 4.6 & 7.5 \\
\hline $\begin{array}{l}\text { Distribution of employment } \\
\text { 0 } \\
1 \\
2 \\
3 \\
4 \\
5-9 \\
10-49 \\
50+\end{array}$ & $\begin{array}{r}59.2 \% \\
14.0 \% \\
9.1 \% \\
4.6 \% \\
3.1 \% \\
6.0 \% \\
4.0 \% \\
0.2 \%\end{array}$ & $\begin{array}{r}47.8 \% \\
11.3 \% \\
11.1 \% \\
6.6 \% \\
5.2 \% \\
9.1 \% \\
7.5 \% \\
1.3 \%\end{array}$ \\
\hline
\end{tabular}

Source: KFS Microdata

In terms of revenues, quite a few of these businesses remain small by any conceivable measure. About 20 percent still have sales of $\$ 5,000$ or less, and about a quarter have assets in that range.
However, many of the firms have grown to be quite large. About 11 percent of firms have revenues of a million dollars or more, and one-third of firms have revenues of between $\$ 100,000$ and $\$ 1,000,000$.

Table 8

Distribution of Revenues and Assets in 2010

\begin{tabular}{|l|r|r|}
\cline { 2 - 3 } \multicolumn{1}{c|}{} & Revenues & \multicolumn{1}{c|}{ Assets } \\
\hline Zero & $11.1 \%$ & $6.7 \%$ \\
\hline$\$ 5,000$ or less & $8.9 \%$ & $16.1 \%$ \\
\hline$\$ 5,001-\$ 25,000$ & $13.6 \%$ & $19.9 \%$ \\
\hline$\$ 25,001-\$ 100,000$ & $23.2 \%$ & $23.6 \%$ \\
\hline$\$ 100,001-\$ 1$ million & $32.4 \%$ & $26.9 \%$ \\
\hline More than $\$ 1$ million & $10.9 \%$ & $6.8 \%$ \\
\hline Total & $\mathbf{1 0 0 . 0} \%$ & $\mathbf{1 0 0 . 0} \%$ \\
\hline
\end{tabular}

Source: KFS Microdata

By 2010, slightly more than half of firms in the KFS had permanently closed down operations. By yearend 2010, 48.9 percent of firms had survived, compared with 55.8 percent at yearend 2009 and 61.3 percent at yearend 2008 . This is comparable to survival rates noted by the Small Business Administration and other government agencies. ${ }^{4}$

Figure 1: Firm Survival 2005-2010

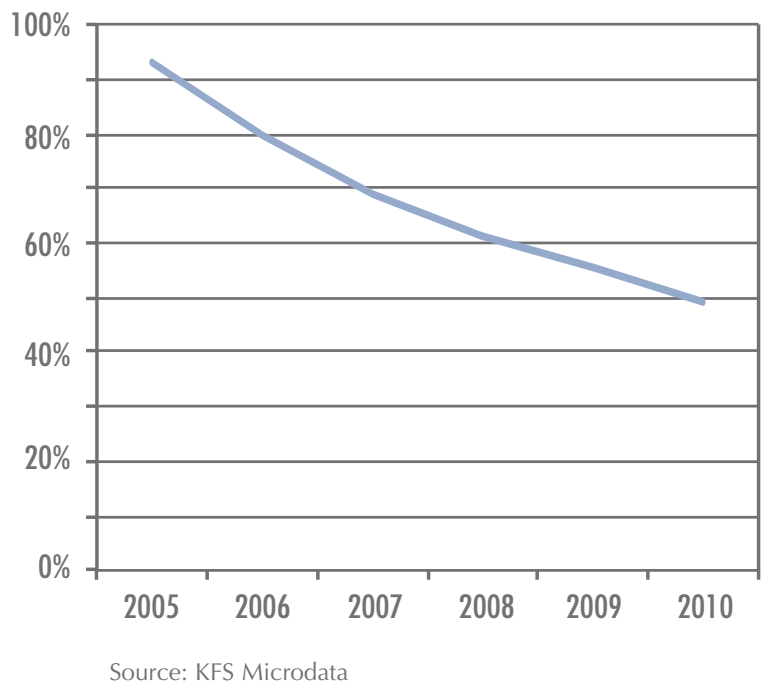

4. http://www.sba.gov/sites/default/files/files/sbfaq.pdf. 


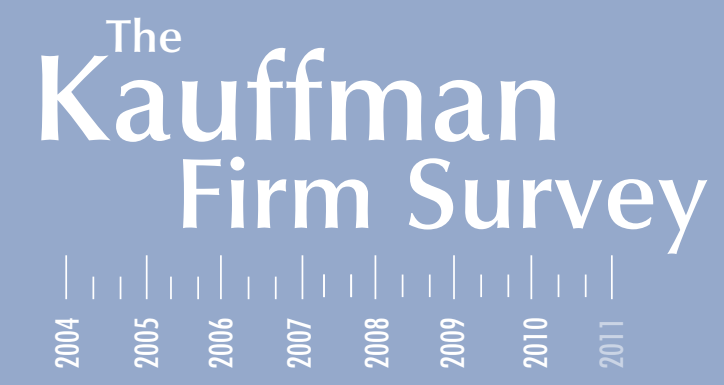




\section{KAUFFMAN}

The Foundation of Entrepreneurship

4801 ROCKHILL ROAD

KANSAS CITY, MISSOURI 64110

816-932-1000

www.kauffman.org 